\title{
COMPARATIVE EVALUATION OF THE RESULTS OF SURGICAL TREATMENT OF ACUTE ASCENDING THROMBOPHLEBITIS OF THE GREAT SAPHENOUS VEIN USING THE ENDOVASCULAR HIGH-FREQUENCY WELDING TECHNIQUE AND TRADITIONAL TECHNIQUE
}

DOI: 10.36740/WLek202004103

\author{
Serhiy I. Savolyuk, Valentyn A. Khodos, Roman A. Herashchenko, Vladyslav S. Horbovets \\ SHUPYK NATIONAL MEDICAL ACADEMY OF POSTGRADUATE EDUCATION, KYIV, UKRAINE
}

\begin{abstract}
The aim of the study was to conduct a comparative evaluation of the effectiveness of surgical treatment of acute ascending thrombophlebitis of the great saphenous vein using the endovascular high-frequency welding technique and traditional phlebectomy.

Materials and methods: Two groups were formed in the conducted study. Group I included patients $(n=42)$ with the acute ascending thrombophlebitis of the great saphenous vein, in whom their thrombosed great saphenous vein was removed using the endovascular high-frequency welding technique. As a source of current, an EK300M1 Svarmed electric welding machine (Ukraine) was used. Electric welding of a thrombosed vein segment was carried out using the endovenous electric welding catheter. Group II included patients $(n=31)$ with the acute ascending thrombophlebitis of the great saphenous vein, who underwent the traditional phlebectomy of the thrombosed great saphenous vein according to Babcock's technique.

Results: In group I no patient revealed presence of pain syndrome with significant intensity during the postoperative period. An infiltrate along the coagulated segments of the great saphenous vein, postoperative oedema and paresthesiae were observed in considerably fewer cases from group I versus group II $(p=0.0005, p=0.0001, p=0.0018)$. During their follow-up for more than 12 months, 2 (4.76\%) of 42 patients from group I revealed partial recanalization of the great saphenous vein ( $p=0.632$ ). In group I the postoperative inpatient period was $1.3 \pm 0.1$ days. In group II the above period averaged $4.8 \pm 0.8$ days $(p<0.001)$. Absence of an intense pain syndrome in group I was caused by a gentle effect of high-frequency electric current itself on the venous wall and paravasal structures. A significant reduction of side effects and complications with a shorter stay of patients in hospital versus the traditional phlebectomy was achieved owing to reduction in the extent of injury of the surgical operation itself with the use of endovascular high-frequency welding.

Conclusions: The technique of endovascular high-frequency welding in treatment of acute ascending thrombophlebitis of the great saphenous vein makes it possible to reduce the extent of injury of the surgical operation versus the traditional phlebectomy, results in a significant decrease in the number of side effects and complications and shortens the period of the patient's stay in hospital.
\end{abstract}

KEY WORDS: acute thrombophlebitis, phlebectomy, high-frequency electrical welding of living tissues

Wiad Lek. 2020;73(4):638-641

\section{INTRODUCTION}

Acute ascending thrombophlebitis of the great saphenous vein is a dangerous complication of the lower extremities varicose veins. Thrombi, which are located proximally to the sapheno-femoral junction, can spread to the common femoral vein with resultant the development of thrombosis of deep veins and thromboembolism $[1,2]$. An examination of 2,484 patients with the superficial thrombophlebitis revealed thrombosis of the deep veins in $18.1 \%$ and pulmonary thromboembolism in $6.9 \%$ of patients with acute thrombophlebitis [3].

Until recent time the surgical treatment of the acute ascending thrombophlebitis of the great saphenous vein consisted in removal of a thrombosed great saphenous vein on a probe or from separate cuts $[4,5,6]$. The high traumatism of the traditional phlebectomy, the large number of complications during the postoperative period and the long rehabilitation time provided the impetus for finding alternative and less traumatic methods of treatment.

Electrical welding of living tissues is one of the above methods $[7,8]$. Connection of tissues with welding results from the effect of electrothermal denaturation of protein molecules caused by passage of high-frequency electric current through tissues [8]. In our previous researches we showed the effectiveness of the use of endovascular high-frequency welding technique for coagulation of the thrombosed great saphenous vein in acute ascending thrombophlebitis of the great saphenous vein [9].

\section{THE AIM}

The purpose of the study was to conduct a comparative evaluation of the effectiveness of surgical treatment of acute 
ascending thrombophlebitis of the great saphenous vein using the endovascular high-frequency welding technique and traditional phlebectomy.

\section{MATERIALS AND METHODS}

During the period of 2016-2018, surgery departments of Kyiv City Hospital No. 8 treated 73 patients with the acute ascending thrombophlebitis of the great saphenous vein. The patients' age ranged from 22 to 78 years (the mean age was $51.4 \pm 3.2$ years). In all cases the acute ascending thrombophlebitis of the great saphenous vein developed in the patients against a background of varicose veins of their lower extremities. The patients were hospitalized urgently. The duration of their disease by the moment of admission to the hospital ranged within 3-14 days. All the patients complained of pain in the area of thrombosed veins, hyperaemia, skin hyperpigmentation over the thrombosed vein area, paravasal oedema and a disrupted function of their extremity.

The intensity of clinical manifestations of the acute ascending thrombophlebitis of the great saphenous vein depended upon the time that had passed after the onset of the disease. According to duplex ultrasound angiography, all the patients were diagnosed to have type III of the acute ascending thrombophlebitis of the great saphenous vein with the floating character of a thrombus. In 63 cases $(86.30 \%)$ the acute ascending thrombophlebitis of the great saphenous vein was combined with the thrombophlebitis of varicose veins on lateral branches of the thigh and lower leg.

All examined cases were divided into two groups.

Group I consisted of 42 patients (14 men (33.33\%) and 28 women $(66.67 \%)$. According to the international CEAP (Clinical Etiological Anatomical Pathophysiological) classification, C2 was revealed in 4 cases, C3 - in 14, C4 - in 9, C5 - in 9 and C6 - in 6. In this group a thrombosed great saphenous vein was removed using the endovascular high-frequency welding technique. As a source of current an EK300M1 Svarmed electric welding machine (Ukraine) was used. Electric welding of a thrombosed vein segment was carried out using the endovenous electric welding catheter.

Group II included 31 patients (11 men (35.48 \%) and 20 women $(64.52 \%)\left(\mathrm{p}_{\mathrm{I}-\mathrm{II}}=0.848\right)$. According to the international CEAP (Clinical Etiological Anatomical Pathophysiological) classification, $\mathrm{C} 2$ was revealed in 6 cases, $\mathrm{C} 3$ - in 9, $\mathrm{C} 4-$ in $11, \mathrm{C} 5-$ in 3 and $\mathrm{C} 6-$ in $2 ;\left(\mathrm{p}_{\mathrm{I}-\mathrm{II}}=0.288\right)$. This group underwent the traditional phlebectomy of the thrombosed great saphenous vein according to Babcock's technique.

The size of trophic ulcers in both groups was up to $4 \mathrm{~cm}$ in diameter. Also, surgical operations in both groups were made under monolateral spinal anaesthesia.

The process of surgical intervention in group I was as follows. In order to isolate the sapheno-femoral junction, J.M. Bruner's access was made as it was the optimum one in terms of the minimum risk of injuring lymph collectors. Crossectomy was performed after J. Bergan with subsequent welding of the stump and subostial branches of the great saphenous vein using the welding jaws. An electric welding catheter was introduced into the thrombosed segment of the great saphenous vein and gradually moved retrogradely in the distal direction to the lower border of the thrombus. Depending upon anatomic peculiarities and localization of the thrombus, in some cases the catheter was introduced and advanced from an access in the upper one-third of the lower leg or in the lower one-third of the thigh in the antegrade direction. The advance and placing of the electric welding catheter in the targeted vein segment were performed under the duplex ultrasound angiography control in B mode. Then tumescence anaesthesia of the targeted great saphenous vein segment under duplex ultrasound angiography control was managed according to the standard technique.

After duplex ultrasound angiograph of the localization of the working part of the electric welding catheter in the targeted area we activated the endovascular high-frequency welding machine with help of its control pedal, as it was evidenced by a sound signal that was heard during the whole active phase in the work of the machine. The process of welding in an isolated vein area $2 \mathrm{~cm}$ long lasted during 5-20 seconds and was accompanied by formation of the typical hyperechogenic «foam». After removal of the catheter from the vein lumen the vein was welded using the welding jaws and the wound was closed in layers.

During the postoperative period the patients from both groups underwent long-term elastic compression on the operated extremity in combination with drug therapy.

Comparative assessment in the groups was carried out on the basis of the following criteria: intensity of pain syndrome in the operated extremity, presence of postoperative haematomata, infiltrates, postoperative oedema, paresthesiae and terms of the patients' stay in hospital. Stability of occlusion in great saphenous vein after the endovascular high-frequency welding was assessed on the basis of the duplex ultrasound angiography data after such terms as 7 days, $1,3,6$ and 12 months.

The rate of side effects and complications was compared by chi square test (with a correction for a small number of observations by Fisher's exact test). The relative risk RR ( $95 \%$ $\mathrm{CI}$ ), was calculated with Haldane-Anscombe correction for values of the rate of complications in the group equal to $0 \%$. The terms of the in-patient period were assessed by $\mathrm{t}$-test.

\section{RESULTS AND DISCUSSION}

The comparative clinical assessment of side effects and complications in patients from groups I and II is presented in table 1.

During our analysis of the data in table 1 it was revealed that presence of significant intensity of pain syndrome within the postoperative period was not observed in any case from group I ( $p=0.0001)$. The patients reported moderate pain in the wound area in the inguinal region and along the coagulated segment of the great saphenous vein. We attribute absence of intense pain syndrome to a gentle effect of high-frequency electric current itself on the venous wall and paravasal structures. Moderate pain was relieved using the tablet analgesics during 12-24 hours. Absence of intense pain in group I made it possible to 
Table 1. The comparative assessment of side effects and complications in the groups.

\begin{tabular}{|c|c|c|c|c|}
\hline Side effects and compications & Group I & Group II & $\begin{array}{l}\text { Relative risk, } \\
\text { RR }(95 \% \mathrm{CI})\end{array}$ & $\mathbf{p}$ \\
\hline Significant intensity of pain syndrome & 0 & $28(90.32 \%)$ & $0.04(0.01-0.25)$ & 0.0001 \\
\hline $\begin{array}{l}\text { Haemorrhage from the bed of the great } \\
\text { saphenous vein }\end{array}$ & 0 & $3(9.68 \%)$ & $0.34(0.06-2.0)$ & 0.160 \\
\hline Haematoma in the bed of the great saphenous vein & 0 & $9(29.03 \%)$ & $0.14(0.02-0.91)$ & 0.0006 \\
\hline Infiltrate & $2(4.76 \%)$ & $12(38.71 \%)$ & $0.21(0.06-0.76)$ & 0.0005 \\
\hline Postoperative oedema & $3(7.14 \%)$ & $18(58.01 \%)$ & $0.19(0.07-0.55)$ & 0.0001 \\
\hline Paresthesia & $4(7.14 \%)$ & $13(41.94 \%)$ & $0.35(0.14-0.83)$ & 0.0018 \\
\hline Recanalization of the great saphenous vein & 2 (4.76\%) & 0 & $1.33(0.73-2.4)$ & 0.632 \\
\hline
\end{tabular}

Notes. Assessment of $p$ by chi square test; assessment of the relative risk with Haldane-Anscombe correction for values of the rate of complications in the group equal to $0 \%$.

activate those patients as early as after one hour following their operation, it being effective prevention of thromboembolic complications.

Intensity of pain syndrome in group II was significant versus group I. Its presence was explained by a large injury of adjacent tissues during removal of the thrombosed great saphenous vein with the use of probe extraction. In this connection it became necessary to use narcotic drugs during the postoperative period.

Unlike the endovascular high-frequency welding, traditional phlebectomy of the great saphenous vein resulted in the formation of a wound canal and, despite suturing of lateral branches and other measures for haemostasis, some patients developed haemorrhage due to the separation of smaller unligated branches, which connected the main trunk with deep or muscle veins. Some cases revealed separation of the vein from the probe with a resultant necessity to make an additional cut in order to remove the remaining vein segment, it increasing the traumatism of the operation. As a result of blood accumulation in the wound tunnel there was formation of haematoma along the removed vein.

An infiltrate along coagulated segments of the great saphenous vein in group I was observed in a considerably less number of patients ( 2 cases, $4.76 \%$ ) versus group II (12 cases, $38.71 \%)(\mathrm{p}=0.0005)$, it corresponding to a reduction of relative risk by $79 \%-\mathrm{RR}=0.21(0.06-0.76)$.

Postoperative oedema in group I was observed in 3 cases (7.14 \%), whereas in group II it was in 18 cases $(58.01 \%)$ $(\mathrm{p}=0.0001)$ (a reduction of relative risk by $81 \%-\mathrm{RR}=0.19$ (0.07-0.55)). Again, this difference can be explained by the fact that energy impact during coagulation of the thrombosed great saphenous vein by the technique of the endovascular high-frequency welding acts, as it was shown in our previous morphological studies, within the borders of the vein walls and practically does not affect adjacent tissues [10]. But the presence of the above side effects and complications in a small number of patients from group I is caused, in our opinion, by use of insufficiently improved welding instruments.

In group II paresthesiae developed much more frequently (13 cases, $41.94 \%)$ than in group I (4 cases,
$7.14 \%)(\mathrm{p}=0.0018)$, it corresponding to a reduction of relative risk in group I by $65 \%-\mathrm{RR}=0.35(0.14-0.83)$. This phenomenon was caused by injuring of branches of the femoral nerve with a probe during stripping because of close topographic-anatomic relations between the above nerve and removed veins.

All the patients from both groups with functional classes C5-C6 revealed regression of clinical manifestations of chronic venous insufficiency and complete epithelialization of trophic ulcers within 30 days after the provided surgical treatment.

Thus, our analysis of the data presented in table 1 showed that in group I versus group II the number of complications was not only much less, but also the extent of their intensity was not significant, thereby demonstrating advantage of the endovascular high-frequency welding over traditional phlebectomy according to Babcock's technique.

By duplex ultrasound angiography data of patients from group I complete occlusion of the great saphenous vein coagulated by the technique of the endovascular high-frequency welding was observed in such terms as 7 days, 1 , 3 , and 6 months. Within the remote period (more than 12 months) 2 of 42 cases $(4.76 \%)$ revealed partial recanalization of the great saphenous vein $(\mathrm{p}=0.632)$. As can be seen from the above, we managed to achieve complete fibrous transformation of coagulated thrombosed great saphenous vein in $95.24 \%$ of cases.

Analysis of treatment results showed significant differences in terms of in-patient stay. A small extent of injury with the endovascular high-frequency welding in the majority of cases from group I made it possible to discharge them from hospital on the day of operation or one day after. While in group I the postoperative inpatient period lasted $1.3 \pm 0.1$ days, in group II the term of their patients' stay in hospital ranged from 4 to 7 days and averaged $4.8 \pm 0.8$ days $(\mathrm{p}<0.001)$.

\section{CONCLUSIONS}

The technique of the endovascular high-frequency welding in treatment of acute ascending thrombophlebitis of the great saphenous vein makes it possible to reduce the 
extent of injury of the surgical operation versus traditional phlebectomy, results in a significant decrease in the number of side effects and complications and shortens the period of the patient's stay in hospital. Follow-up after the endovascular high-frequency welding of great saphenous vein during more than 12 months revealed complete fibrous transformation of the coagulated vein in $95.24 \%$ of cases. Achievement of better results in treatment of acute ascending thrombophlebitis of the great saphenous vein with use of the endovascular high-frequency welding necessitates improvement of surgical instruments and technique of the surgical operation itself.

\section{REFERENCES}

1. Frappé P., Buchmuller-Cordier A., Bertoletti L. etal. Annual diagnosis rate of superficial vein thrombosis of the lower limbs: the STEPH communitybased study. Journal of Thrombosis and Haemostasis. 2014;12:831-838.

2. Reynaud Q., Catella J., Diconne E. et al. Pas de chirurgie sans échographie préalable en cas de thrombose veineuse superficielle clinique à propos d'un cas d'embolie paradoxale grave. Annales Françaises d'Anesthésie et de Réanimation. 2014;33(1):41-43.

3. Di Minno M.N., Ambrosino P., Ambrosini F. et al. Prevalence of deep vein thrombosis and pulmonary embolism in patients with superficial vein thrombosis: a systematic review and meta-analysis. Journal of Thrombosis and Haemostasis. 2016;14(5):964-972.

4. Savelieva V.S., Kirienko A.I., editors. Vascular surgery. National leadership. M.: GEOTAR-Media; 2014, p. 464. (Ru)

5. Tsarev 0.A., Anisimov A.Yu., Zakharov N.N., et al. Hirurgicheskaja taktika u bolnyh varikotromboflebitom s nedifferencirovannoj displaziej soedinitelnoj tkani. [Surgical approach to patients with varicothrombophlebitis with undifferentiated dysplasia of connective tissue]. Saratov Journal of Medical Scientific Research. 2016;12(1):6670. (Ru)

6. Chernukha L.M., Shchukin S.P. Trombotychni uskladnennja tjazhkyh form varykoznoi hvoroby: diagnostyka, hirurgichne likuvannja z zastosuvannjam miniinvazyvnyh metodiv. [Thrombotic complications in severe forms of varicose disease: diagnosis, surgical treatment using miniinvasive methods]. Klinichna Khirurgiia. 2015;1:35-37. (Ua)

7. Marinsky G.S., Chernets A.V., Tkachenko V.A. et al. Stendovye issledovanija vysokochastotnoj jelektrosvarki biologicheskih tkanej [The poster researches of high-frequency electric welding of biological tissues]. Automatic welding. 2016;12(759):41-45. (Ru)

8. Paton B.E., Krivtsun I.V., Marinsky G.S. et al. Svarka, rezka itermicheskaja obrabotka mjagkih tkanej [Welding, cutting and heat treatment of soft tissue]. Automatic welding. 2013;10-11:135-146. (Ru)
9. Savoluk S.I., Khodos V.A., Gerashchenko R.A. et al. Pershij dosvid vikoristannja endovenoznogo elektrozvarjuvannja v kompleksnomu hirurgichnomu likuvanni gostrogo vishidnogo tromboflebitu velikoï pidshkirnoï veni [The first experience of using endovascular electric welding in the complex surgical treatment of acute ascending thrombophlebitis of a large subcutaneous vein]. Surgery of Ukraine. 2018;3(67):63-67. Dol: http: //doi.org/10.3978/SU2018-3-63 ISSN 1818-5398. (Ua)

10. Dyadyk 0.0., Savolyuk S.I., Gerashchenko R.A. et al. Morfologichne obgruntuvannja vyboru optymalnyh parametriv endovenoznogo elektrozvarjuvannja dlja likuvannja vyshidnogo tromboflebitu velykoi pidshkirnoi veny. [Morphological substance of the selection of optimal parameters of endovenous electric welding for treatment of ascending thrombophlebitis of great saphenous vein]. Art of medicine. 2018;3(7):49-53. (Ua)

\section{ORCID and contributionship:}

Serhiy I. Savolyuk - 0000-0001-5406-8228 B,F

Valentyn A. Khodos - 0000-0003-0150-3868 ${ }^{A, F}$

Roman A. Herashchenko - 0000-0001-6582-9934 C,D,E,F

Vladyslav S. Horbovets - 0000-0003-1744-9544 D,E,F

\section{Conflicts of interest:}

Authors declare no conflict of interest.

\section{CORRESPONDING AUTHOR} Roman A. Herashchenko

Department of surgery and vascular surgery,

Shupyk National Medical Academy of Postgraduate Education

str. Salyutnaya 19, apt. 19, 04111, Kyiv, Ukraine

tel: +380971090930

e-mail: patholognew@ukr.net

Received: 11.10 .2019

Accepted: 20.02 .2020

A - Work concept and design, B - Data collection and analysis, C - Responsibility for statistical analysis, D-Writing the article, $\mathbf{E}$-Critical review, $\mathbf{F}$ - Final approval of the article 